\title{
Pengendalian Hama Penggerek Bonggol Pisang (Cosmopolites sordidus. Germar) Dan Penggerek Batang Pisang (Odoiphorus longicollis. Olivier) Dengan Beauveria bassiana
}

\section{The Control of The Bannes Bonggol Banana (Cosmopolites sordidus. Germar) and The Banner Steam Builder (Odoiphorus longicollis. Olivier) With Beauveria bassiana}

\author{
Agung Syahputra, Suswati, dan Asmah Indrawati \\ Fakultas Pertanian, Universitas Medan Area, Indonesia \\ *Corresponding author: E-mail: agungumafp@gmail.com
}

\begin{abstract}
Abstrak
Tujuan dari penelitian ini adalah untuk menggali informasi tentang kemampuan cendawan Beauveria bassiana dalam mengurangi intensitas serangan penggerek bonggol dan penggerek batang pisang. Penelitian ini dilakukan di Desa Lao Sambo, Kecamatan STM Hulu Kabupaten Deli Serdang, dengan ketinggian tempat $150 \mathrm{mdpl}$. Penelitian ini menggunakan Rancangan Acak Kelompok (RAK) non faktorial dengan 6 taraf perlakuan, 4 ulangan, perlakuan adalah aplikasi jenis B. bassiana dengan dosis rekomendasi. sebagai berikut : $\mathrm{A} 0=0$ konidia $/ \mathrm{ml}, \mathrm{A} 1=10^{2} \mathrm{konidia} / \mathrm{ml}, \mathrm{A} 2=10^{4} \mathrm{konidia} / \mathrm{ml}, \mathrm{A} 3=10^{6}$ konidia $/ \mathrm{ml}, \mathrm{A} 4=10^{8} \mathrm{~A} 5=$ sipermetrin $0,5 \mathrm{cc} / \mathrm{ml}$. Parameter yang diamati meliputi mortalitas C.sordidus dan O.longicollis dan efektifitas dosis B.bassiana. C.sordidus Germar dan O.longicollis Oliver yang terperangkap lebih didominasi oleh trap A0 (kontrol) $75 \%$ sedangkan A1 (suspensi 10²/ml) $0 \%$, A2 (suspensi 104/ml) 14,29\%, A3 (suspensi 106/ml) $0 \%$, A4 (suspensi 108/ml) 10,71 \%, dan A5 (Sipermetrin 0,5cc/ml) $0 \%$ imago. Sedangkan O.longicollis pada trap A0 (kontrol) 39,13 \% sedangkan A1 (suspensi 102/ml) 34,78 \%, A2 (suspensi 104/ml) $0 \%$, A3 (suspensi 10\% $/ \mathrm{ml}$ ) 21,74\%, A4 (suspensi $10^{8} / \mathrm{ml}$ ) 4,35\% ekor, dan A5(Sipermetrin 0,5 ml) $0 \%$ imago. Penggunaan suspensi jamur B.bassiana sangat berpengaruh nyata terhadap C.sordidus Germar dan O.longicollis Oliver yang terperangkap pada trap.
\end{abstract}

Kata Kunci: Pengendalian, Penggerek Bonggol Pisang, Penggerek Batang Pisang, Beauveria bassiana

\begin{abstract}
The purpose of this study was to explore information about the ability of the fungus Beauveria bassiana in reducing the intensity of borer attack and banana stem borer. This research was conducted in Lao Sambo Village, District of STM Hulu Kabupaten Deli Serdang, with altitude of place $150 \mathrm{mdpl}$. This study used non factorial Randomized Block Design (RAK) with 6 treatment levels, 4 replicates, treatment was application of $B$. bassiana type with recommendation dose. as follows: $A 0=0$ conidia $/ \mathrm{ml}, A 1=102$ conidia $/ \mathrm{ml}, A 2=$ 104 conidia $/ \mathrm{ml}, \mathrm{A3}=106$ conidia $/ \mathrm{ml}, \mathrm{A4}=108 \mathrm{A5}=0.5 \mathrm{~cm}$ sipermetrin $/ \mathrm{ml}$. Parameters observed included mortality of C.sordidus and O.longicollis and the effectiveness of the dosage of B.bassiana. C.sordidus Germar and O.longicollis The trapped oligate was dominated by a 75\% AO (control) trap while A1 (suspension $102 / \mathrm{ml}$ ) 0\%, A2 (104/ml suspension 14.29\%, A3 (suspension 106/ml) 0\%, A4 (108/ml suspension) 10,71\%, and A5 (Sipermetrin 0,5cc / ml) 0\% imago. While O.longicollis on trap AO (control) 39,13\% while A1 (suspension $102 / \mathrm{ml}$ ) 34,78\%, A2 (suspension $104 / \mathrm{ml}$ ) 0\%, A3 (suspension $106 / \mathrm{ml}$ ) 21,74\%, A4 (suspension $108 / \mathrm{ml}$ ) 4.35\% of the tail, and A5 (Sipermetrin $0.5 \mathrm{ml}$ ) 0\% imago. The use of suspension of the fungus B.bassiana very significant effect on C.sordidus Germar and O.longicollis Oliver who trapped on the trap.
\end{abstract}

Keywords : Control, Banana Stalker, Banana Stalker, Beauveria bassiana

How to Cite: Syahputra A., Suswati, dan Asmah I., (2016), Pengendalian Hama Penggerek Bonggol Pisang (Cosmopolites sordidus. Germar) Dan Penggerek Batang Pisang (Odoiphorus longicollis. Olivier) Dengan Beauveria bassiana, Jurnal Agrotekma, 1 (1): 69-80 


\section{PENDAHULUAN}

Di Indonesia tanaman pisang adalah komoditas hortikultura yang sangat berperan diversifikasi sumber pangan, ekonomi dan aktifitas budaya, pisang merupakan buah yang banyak tumbuh di daerah-daerah di Indonesia. Produksi pisang di Indonesia mencapai 5 juta ton pada tahun 2008 (Apriliani, 2013). Produksi pisang Indonesia cukup besar, berdasarkan Angka Tetap (ATAP) tahun 2013 produksi pisang mencapai 6,28 juta ton. Untuk wilayah Asia, Indonesia termasuk penghasil pisang terbesar karena $50 \%$ produksi pisang Asia dihasilkan oleh Indonesia, hampir seluruh wilayah Indonesia merupakan daerah penghasil pisang karena didukung oleh iklim yang sesuai. Pengembangan dan persebaran pisang dipengaruhi oleh beberapa factor, antara lain iklim, media tanam dan ketinggian tempat, namun demikian $90 \%$ produksi pisang masih digunakan untuk konsumsi dalam negeri, sedangkan untuk ekspor hanya 10\% (Suhartanto et al. 2008).

Di Sumatera Utara pada tahun 2006 luas panen tanaman pisang di Sumatera Utara mencapai 11.531 ha dengan total produksi 207.832 ton, total panen tersebut terutama dihasilkan oleh kabupaten Deli serdang, Simalungun, Tapanuli Tengah, Nias, Tanah Karo, Asahan, Tapanuli Selatan dan Serdang Bedagai. Rata-rata produksi tanaman pisang di Sumatera Utara berkisar 7,273 ton/ha hingga 20,00 ton/ha. (Dinas Pertanian Sumatera Utara 2006). Pada tahun 2005, pisang barangan merupakan buah unggulan propinsi Sumatera Utara dengan produksi sebesar 134.276 ton dan luas areal 3.047 Ha. Pisang sendiri memiliki kandungan karbohidtrat, kalsium, fosfor, potasium, vitamin C, vitamin $\mathrm{A}$, thiamine, riboflavin dan niacin, setiap $100 \mathrm{~g}$ pisang mengandung $120 \mathrm{kal}$, vitamin A-nya 2 kali lipat buah apel dan memiliki kandungan $\mathrm{K}$ tertinggi diantara buah.

Itulah sebabnya pisang mampu menjadi pangan utama dan komoditas sehat untuk diet dibanyak negara di dunia, termasuk dari ketergantungan terhadap beras dan komoditi pangan lainnya. Sedangkan nilai ekspornya adalah US $\$ 0,54$ juta yang kemudian meningkat pesat menjadi US\$22,65 juta pada tahun 2006. Juga mengemukakan bahwa pisang pernah menguasai sampai dengan $52 \%$ total ekspor buah Indonesia, antara 70-90\% dari produksi pisang di Indonesia, berasal dari tanaman pekarangan dan kebun skala kecil. Berdasarkan Sensus Pertanian Tahun 2013 (Badan Pusat Statistik, 2014), rumah tangga tani yang terlibat dalam budidaya pisang di Indonesia sebanyak 5,41 juta atau 51,03\% dari rumah tangga hortikultura yang berjumlah 10,60 juta rumah tangga. Kultivasi pisang di Indonesia dihadang oleh masalah hama dan penyakit, ketika hasil tanaman pisang petani rendah, petani akan menelantarkan tanaman pisang meraka, dan kumbang C.sordidus dan O.longicollis telah diidentifikasi sebagai hama terpenting pada tanaman pisang (Umeh et al. 2005).

Gejala serangan C.sordidus dan O.longicollis dapat teridentifikasi seperti mengganggu menginisiasi akar, nutrisi, transportasi, mengakibatkan kekerdilan, pematangan buah tertunda, ukıran buah kecil dan bahkan batang ta an pisang menjadi patah. Di Indonesia sendiri pengendaian hama C.sordidus dan 
O.longicollis hanya dilakukan seperti, menanam kembali varietas yang tahan oleh serangan hama tersebut, kemudian membersihkan pelepah tua, menyebarkan predator Plaseus javanicus er dan mensanitasi tanaman pisang. (Deptan go.id, 2014). Di Sumatera Utara sendiri Data Badan Pusat Statistik Sumatera Utara (2012) menunjukkan produksi pisang barangan mengalami peningkatan mencapai angka 15.793 ton dengan luas areal 13.787 ha, atau produksinya/ha $11,46 \mathrm{kw} / \mathrm{ha}$.

Jika dibandingkan dengan produksi tahun 2010 yang hanya mencapai 7.043 ton dengan luas areal $6.311 \mathrm{ha}$, atau produksinya/ha 5,66 kw/ha. Sementara produksi pisang barangan di Nias Utara pada tahun 2012 mengalami peningkatan mencapai 2.025 ton dengan luas areal 1.814 ha, jika dibandingkan dengan produksi tahun 2010 yang hanya mencapai 1.906 ton dengan luas areal 1.695 ha. Pisang barangan mempunyai kandungan gizi yang sangat baik dan kaya mineral seperti kalium, magnesium, fosfor, besi, dan kalsium. Selain itu pisang barangan juga mengandung vitamin $\mathrm{C}, \mathrm{B}$ kompleks, B6, dan serotonin yang aktif sebagai neurotransmitter dalam kelancaran fungsi otak. Oleh karena itu pisang barangan menjadi alternatif terbaik, sebagai sumber energi pada saat istirahat (Sunyoto, 2011).

\section{METODE PENELITIAN}

Bahan dan alat yang digunakan adalah: Isolat murni jamur B.bassiana, media PDA, pipet tetes, bahan aktif (sipermetrin) $250 \mathrm{EC}$, aquades steril 1 liter, spirtus 1 liter, aluminium poil 1 gulung, jarum inokulasi, alat tulis, ent case (kotak inokulasi), nampan, panci, cawan petri dan oven, autoclave atau hotplate, toples ukuran $20 \mathrm{x} 25 \mathrm{~cm}$, haemocytometer, spatula, tabung reaksi.

Menggunakan Rancangan Acak Kelompok (RAK) non faktorial dengan 6 taraf perlakuan, dan 4 ulangan. Perlakuan adalah aplikasi jenis $B$. bassiana dengan dosis rekomendasi sebagai berikut :

$$
\begin{aligned}
& \text { A0 }=0 \text { (konidia } / \mathrm{ml}), \\
& \text { A1 }={ }_{10^{2}}(\text { konidia } / \mathrm{ml}), \\
& \text { A2 }={ }_{10^{4}}(\text { konidia } / \mathrm{ml}), \\
& \text { A3 }={ }_{10^{6}}(\text { konidia } / \mathrm{ml}), \\
& \text { A4 } \left.={ }_{10^{8}} \text { (konidia } / \mathrm{ml}\right), \\
& \text { A5 }=\text { Insektisida }(\text { Sipermetrin) EC } 0,5 \\
& \text { cc } / \text { ml }
\end{aligned}
$$

Model linear yang diasumsikan untuk Rancangan Acak Kelompok non faktorial, yaitu : Yij $=\mu+\alpha ́ \alpha+B j+€ i j$

Keterangan :

Yij = Hasil atau nilai pengamatan dari perlakuan ke I dan ulangan ke $\mathrm{j}$

$\mu \quad=$ Nilai tengah umum

ói = Pengaruh perlakuan ke i

$\mathrm{Bj} \quad=$ Pengaruh blok ke $\mathrm{j}$

Analisis dilakukan secara statistik terhadap banyaknya konidia yang menginfeksi serangga, rata-rata pertambahan serangga yang terkena infeksi B.bassiana, Pertambahan konidia pada serangga, selanjutnya diuji dengan rumus regresi. Adapun paremeter pengamatan pada penelitian ini yaitu : pengamatan morfologi $b$. Bassiana, kepadatan populasi c.sordidus germar dan o.longicollis oliver, persentase mortalitas 
serangga c.sordidus dan o.longicollis, efektifitas bioinsektisida b.bassiana, dan metode analisis data.

Penelitian ini terdiri dari 4 tahap, yaitu :

Pembuatan PDA dilakukan dengan : mengupas 200 gram kentang, dicuci bersih lalu dipotong kecil-kecil ukuran $1 \mathrm{~cm} \times 1 \mathrm{~cm}$ dan direbus dalam 1 liter akuades sampai lunak. Kemudian disaring untuk memisahkan air dengan kentang, sari kentang sebanyak 1 liter ditambahkan dengan 20 gr agar dan 20 gr dextrose, lalu direbus lagi sampai mendidih. Setelah itu, larutan tersebut disaring kembali dan dituangkan pada botol untuk disterilkan dalam autoclave selama 15 menit suhu $121^{\circ} \mathrm{C}$ dan tekanan 1 atmosfer (atm).

Penyiapan suspensi B.bassiana dilakukan di laboratorium Universitas Medan Area Fakultas Pertanian, indukan B.bassiana diperoleh dari koleksi Balai Besar Proteksi Tanaman Perkebunan Medan yang asalnya dari Hypothenemus hampei hama tanaman coklat yang terinfeksi B.bassiana, isolat yang digunakan adalah F2 dari induk aslinya, kemudian dibiakkan lagi dengan media baru selama 10 hari. Berikut cara kerja pembuatan suspensi B.bassiana:

Perbanyakan B.bassiana pada PDA sebanyak 10 cawanpetri kemudian diinkubasikan selama 72 jam pada suhu ruang $29^{\circ} \mathrm{C}$, kemudian menambahkan 10 $\mathrm{ml}$ akuades steril kedalam biakan B.bassiana.

B.bassiana, kemudian diaduk dengan spatula hingga spora B.bassiana naik ke permukaan lalu diambil dengan mikro pipet sebanyak $1 \mathrm{ml}$, setelah itu menyiapkan tabung reaksi sebanyak 8 tabung reaksi dan 1 starter yang diberi aquades masing-masing sebanyak $9 \mathrm{ml}$, kemudian teteskan masing-masing $1 \mathrm{ml}$ ke masing-masing tabung reaksi lalu ambil sampel B.bassiana yang telah diencerkan tersebut lalu amati dengan Haemocytometer, kemudian apabila sudah ditemukan konidia yang sudah ditentukan $10^{2}, 10^{4}, 10^{6}, 10^{8}$, maka selanjutnya, membuat suspensi larutan yang akan dipersiapkan untuk dilakukan pengaplikasian dilapangan.

Waktu yang efektif untuk pemasangan disc on corm trap pada sekeliling batang pisang yakni pada sore hari, dikarnakan suhu dan kelembaban pada sore hari sudah mulai menurun, karena pada sore hari kumbang C.sordidus dan O.longicollis mulai aktif mencari makanannya, karena kumbang C.sordidus dan O.longicollis bersifat aktif pada sore dan malam hari atau aktifitas hidupnya dimulai pada sore dan malam hari (Nocturnal). Maka dari itu mengapa alasan yang tepat untuk memasang disc on corm trap, cara pembuatan trap sangat sederhana dengan menggunakan batang semu pisang barangan yang masih segar dan sudah dipanen, panjangnya kira-kira 25-50 cm lalu bersihkan permukaannya dan kemudian batang pisang tersebut dibelah dua, lalu trap tersebut diletakkan dimasing-masing tanaman pisang sesuai perlakuan lalu diaplikasikan dengan disemprotkan suspensi B.bassiana sesuai dengan perlakuan masing-masing perangkap, kemudian di letakkan trap tersebut di dekat akar atau disekitar tanaman pisang, trap ditutup dengan batang pisang yang berguna untuk menjaga kelembaban batang pisang (Gambar 1). 

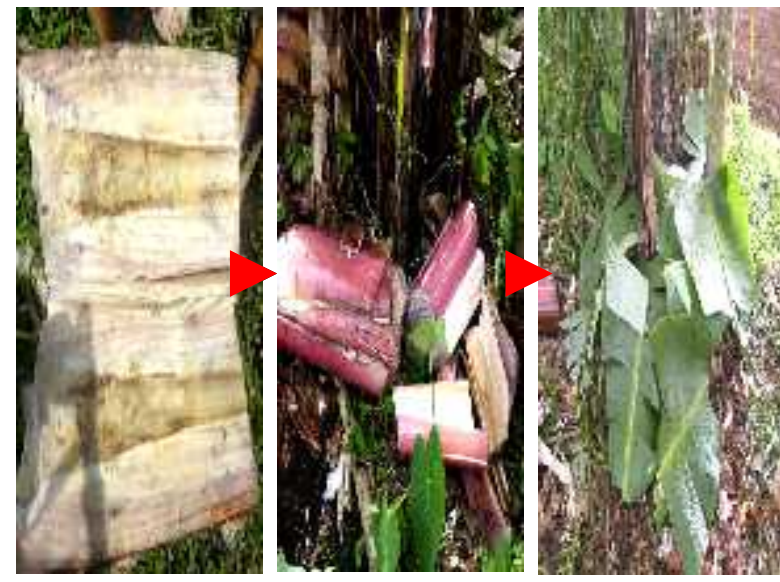

Gambar 1. Perangkap bonggol pisang untuk menangkap hama penggerek batang dan bonggol pisang. Sumber Mairawita, et al 2012.

Setelah 2 hari kemudian perangkap akan dikunjungi oleh hama penggerek bonggol dan penggerek batang pisang, serangga kemudian dipelihara didalam toples yang berukuran $25 \mathrm{~cm} \mathrm{x} 20 \mathrm{~cm}$. Pengumpulan serangga penggerek batang masuk kedalam perangkap dikumpulkan setiap 2 hari selama 6 hari, setelah itu ditempatkan di Laboratorium pada suhu $23^{\circ} \mathrm{C}$ dan kelembaban $80 \%$. Penggantian sumber makanan berupa potongan batang pisang dilakukan setiap 2 hari sekaligus dilakukan penghitungan jumlah serangga yang mati.

Selanjutnya hasil penangkapan serangga C.sordidus dan O.longicollis di lapangan kemudian dibawa ke laboratorium untuk dipelihara guna untuk mengetahui efektifitas B.bassiana yang menginfeksi serangga C.sordidus dan O.longicollis yang terperangkap di trap, kemudian diamati dan mengganti makanan setiap 2 kali sehari sampai serangga C.sordidus dan O.longicollis seluruh bagian tubuhnya terinfeksi B.bassiana.

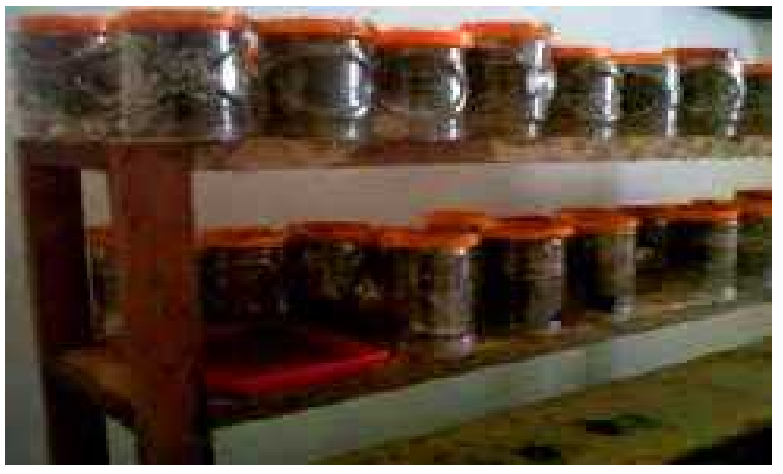

Gambar 2.Pemeliharaan C.sordidus dan O.longicollis di laboratorium (Dokumentasi Pribadi 2014)

\section{HASIL DAN PEMBAHASAN}

Pengamatan Morfologi B.bassiana

Morfologi hifa, dan koloni diamati dengan menggunakan mikroskop binokular dengan perbesaran 600x. Warna koloni diamati secara visual dan pertumbuhan koloni diamati dengan mengukur pertambahan diameter koloni B. bassiana pada umur 3-10 hari setelah inkubasi, berikut tabel hasil penjelasan data pengamatan morfologi B.bassiana :

\begin{tabular}{lll}
\hline No & \multicolumn{1}{c}{ Umur Biakan B.bassiana / hari } & $\begin{array}{c}\text { Keterangan/ } \\
\mathrm{cm}\end{array}$ \\
\hline 1 & $\begin{array}{l}\text { Biakan B.bassiana } \\
\text { umur 1 hari }\end{array}$ & Diameternya - cm \\
\hline 2 & $\begin{array}{l}\text { Biakan B.bassiana } \\
\text { umur 2 hari }\end{array}$ & Diameternya $1 \mathrm{~cm}$ \\
\hline 3 & $\begin{array}{l}\text { Biakan B.bassiana } \\
\text { umur 3 hari }\end{array}$ & Diameternya $1^{1 / 2} \mathrm{~cm}$ \\
\hline 4 & $\begin{array}{l}\text { Biakan B.bassiana } \\
\text { umur 4 hari }\end{array}$ & Diameternya $2 \mathrm{~cm}$ \\
\hline 5 & $\begin{array}{l}\text { Biakan B.bassiana } \\
\text { umur 5 hari }\end{array}$ & Diameternya $2^{1 / 2} \mathrm{~cm}$ \\
\hline 6 & $\begin{array}{l}\text { Biakan B.bassiana } \\
\text { umur 6 hari }\end{array}$ & Diameternya $3 \mathrm{~cm}$ \\
\hline 7 & $\begin{array}{l}\text { Biakan B.bassiana } \\
\text { umur 7 hari }\end{array}$ & Diameternya $3^{1 / 2} \mathrm{~cm}$ \\
\hline 8 & $\begin{array}{l}\text { Biakan B.bassiana } \\
\text { umur 8 hari }\end{array}$ & Diameternya $4 \mathrm{~cm}$ \\
\hline 9 & $\begin{array}{l}\text { Biakan B.bassiana } \\
\text { umur 9 hari }\end{array}$ & Diameternya $4^{1 / 2} \mathrm{~cm}$ \\
\hline 10 & $\begin{array}{l}\text { Biakan B.bassiana } \\
\text { umur 10 hari }\end{array}$ & Diameternya $5 \mathrm{~cm}$ \\
\hline
\end{tabular}




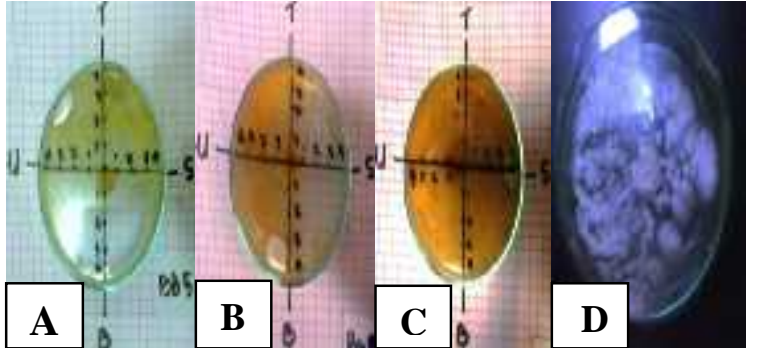

Gambar 3. Biakan B.bassiana dalam medium PDA dari umur 3-10A). Koloni B.bassiana dalam PDA umur 1 hari. B). Koloni B.bassiana dalam PDA umur 3 hari. C). Koloni B.bassiana dalam PDA umur 5 hari D). Koloni B.bassiana dalam PDA umur 7 hari (Dokumentasi pribadi 2014).

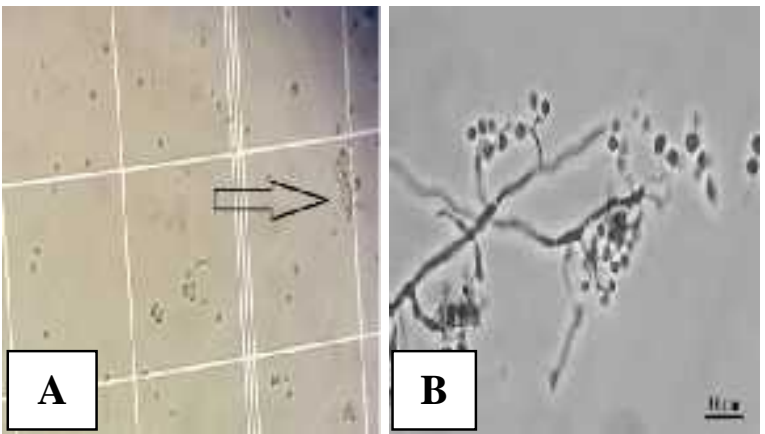

Gambar 4. Konidia B.bassiana dengan perbesaran $300 \times$ (Dokumentasi pribadi dan http. // www. Konidia B.bassiana dalam perbesaran 300x.com. 2014).

Koloni $B$. bassiana pada medium PDA yang diinkubasi pada suhu $25-30^{\circ} \mathrm{C}$ dan berumur 14 hari, membentuk lapisan seperti tepung. Koloni pada bagian tepi mula-mula berwarna putih kemudian menjadi kuning pucat. (Ahmad 2008). Kematian serangga dapat terjadi dalam waktu 7 hari setelah aplikasi. (Soetopo dan Indrayani, 2007).

Persentase Mortalitas C.sordidus dan O.longicollis

C.sordidus yang terperangkap lebih didominasi oleh trap A0 (kontrol) 21 ekor sedangkan A1 (suspensi $10^{2} / \mathrm{ml}$ ) 0 ekor, A2 (suspensi $10^{4} / \mathrm{ml}$ ) 4 ekor, A3 (suspensi
106 $/ \mathrm{ml}$ ) 0 ekor, A4 (suspensi 108/ml) 3 ekor, dan A5 (Sipermetrin 0,5 cc/ml tidak ada C.sordidus dan O.longicollis yang terperangkap, O.longicollis pada trap A0 (kontrol) 9 ekor sedangkan A1 (suspensi $10^{2} / \mathrm{ml}$ ) 8 ekor, A2 (suspensi $10^{4} / \mathrm{ml}$ ) 0 ekor, A3 (suspensi $10^{6} / \mathrm{ml}$ ) 5 ekor, A4 (suspensi $10^{8} / \mathrm{ml}$ ) 1 ekor, dan A5 (Sipermetrin 0,5cc/ml) 0 ekor.

Persentasi pengamatan mortalitas meliputi C.sordidus dan O.longice $s$ dapat diamati pada hari ke-3 sampai 30 hari setelah inokulasi dengan interpal 2 hari penggantian makanan dengan cacahan batang pisang, dari tabel 4.2 didapat hasil mortalitas dari jenis C.sordidus dan O.longicollis. Dari data tabel 4.2 dapat kita lihat jumlah imago C.sordidus dan imago O.longicollis terperangkap ditrap. C.sordidus yang terperangkap pada trap A0 (kontrol) 0 \% sedangkan A1 (suspensi $10^{2} / \mathrm{ml}$ ) $0 \%$, A2 (suspensi $10^{4} / \mathrm{ml}$ ) 57,14 $\%$, A3 (suspensi 106/ml) $0 \%$, A4 (suspensi $10^{8} / \mathrm{ml}$ ) 42,86 \%, dan A5 (Sipermetrin $0,5 \mathrm{cc} / \mathrm{ml}) \quad 0 \quad \%$ imago. Sedangkan O.longicollis yang tereperangkap pada trap A0 (kontrol) $0 \%$ sedangkan A1 (suspensi $10^{2} / \mathrm{ml}$ ) 57,14 \%, A2 (suspensi $10^{4} / \mathrm{ml}$ ) 0 $\%$, A3 (suspensi $10^{6} / \mathrm{ml}$ ) 35,71\%, A4 (suspensi $10^{8} / \mathrm{ml}$ ) 7,14\% ekor, dan A5 (Sipermetrin 0,5 cc/ml) $0 \%$.

Semakin tinggi konsentrasi $B$. bassiana maka mortalitas semakin tinggi pula dan semakin lanjut stadia perkembangan serangga maka semakin rendah mortalitas serangga. Atmadja et al. (2000). Herlinda (2010) menyatakan bahwa perbedaan mortalitas serangga inang oleh jamur entomopatogen karena adanya perbedaan viabilitas dan virulensi konidia. 
Tabel 2. Mortalitas dan lama kematian C.sordidus Germar dan O.longicollis Oliver Setelah Di Aplikasi Suspensi B.bassiana.

\begin{tabular}{|c|c|c|c|c|c|}
\hline \multirow[t]{2}{*}{ Perlakuan } & \multirow[t]{2}{*}{ Kode } & \multicolumn{2}{|c|}{ Mortalitas (\%) } & \multicolumn{2}{|c|}{$\begin{array}{l}\text { Waktu mulai saat ter } \\
\text { infeksi sampai serangga } \\
\text { mati }\end{array}$} \\
\hline & & C.s & 0.1 & C.s & 0.1 \\
\hline Kontrol & A0 & 0 & 0 & 0 & 0 \\
\hline B.bassiana $10^{2} / \mathrm{ml}$ & A1 & 0 & 57,14 & 0 & 5 \\
\hline B.bassiana $10^{4} / \mathrm{ml}$ & A2 & 57,14 & 0 & 6 & 0 \\
\hline B.bassiana $10^{6} / \mathrm{ml}$ & A3 & 0 & 35,71 & 0 & 5 \\
\hline B.bassiana $10^{8} / \mathrm{ml}$ & A4 & 42,86 & 7,14 & 5 & 5 \\
\hline Sipermetrin $0,5 \mathrm{cc} / \mathrm{ml}$ & A5 & 0 & 0 & 0 & 0 \\
\hline
\end{tabular}

Kepadatan Populasi C.sordidus Germar dan O.longicollis Oliver

Hasil pengamatan hari pertama sampai hari ketiga pemberian isolat murni B.bassiana dari beberapa perlakuan terhadap pengendalian imago C.sordidus dan O.longicollis sampai dewasa. Imago C.sordidus banyak yang terperangkap pada perlakuan kontrol (A0), hari pertama sampai hari ketiga pengamatan bejumlah 21 ekor, perlakuaan A1 (10²) tidak ada yang terperangkap imago pengerek C.sordidus dari pengamatan hari pertama sampai hari ketiga, perlakuaan A2 (104) imago yang terperangkap dari hari pertama sampai hari ketiga berjumlah 4 ekor imago C.sordidus, perlakuan A3 (106) tidak ada imago O.longicollis yang terperangkap dari hari pertama sampai hari ketiga pengamatan, perlakuan A4 $\left(10^{8}\right)$ imago C.sordidus pisang yang terperangkap berjumlah 3 ekor dari pengamatan perama sampai pengamatan ketiga, sedangkan pada perlakuan A5 (Sipermetrin EC 0,5cc/liter) 0 ekor, imago yang terperangkap dari pengamatan hari pertama sampai hari ketiga. perlakuan A0 (kontrol) jumlah O.longicollis yang terperangkap dari hari pertama sampai hari ketiga berjumlah 9 ekor, perlakuan A1 (10²) O.longicollis yang terperangkap dari hari pertama sampai hari ketiga berjumlah 8 ekor, perlakuan A2 $\left(10^{4}\right)$ tidak ada O.longicollis yang terperangkap dari pengamatan pertama sampai pengamatan ketiga, perlakuan A3 $\left(10^{6}\right)$ jumlah O.longicollis yang terperangkap dari pengamatan pertama sampai pengamatan ketiga sebanyak 5 ekor, pada A4 $\left(10^{8}\right)$ imago O.longicollis yang terperangkap 1 ekor dari pengamatan pertama sampai pangamatan ketiga, sedangkan perlakuan A5 (Sipermetrin EC 0,5cc/liter) tidak ada serangga batang pisang dan penggerek bonggol pisang yang terperangkap dari pengamatan pertama sampai ketiga. Serangga penggerek bonggol dan serangga penggerek batang pisang yang didapatkan setelah diidentifikasi dihitung jumlahnya.(Michael, 1984). Jumlah serangga C.sordidus dan O.longicolli yang terperangkap pada disc corm on trap dapat dilihat pada Tabel 3 
Tabel 3. Kepadatan populasi C.sordidus dan O.longicollis yang terperangkap pada perlakuan B.bassiana.

\begin{tabular}{|c|c|c|c|}
\hline \multirow[t]{2}{*}{ Perlakuan } & \multirow[t]{2}{*}{ Kode } & \multicolumn{2}{|c|}{$\begin{array}{l}\text { Jumlah C.sordidus dan } \text { O.longicollis yang } \\
\text { terperangkap pada trap. }\end{array}$} \\
\hline & & C.sordidus & O.longicolli \\
\hline Kontrol & A0 & 21 & 9 \\
\hline B.bassiana $10^{2} / \mathrm{ml}$ & A1 & 0 & 8 \\
\hline B.bassiana $10^{4} / \mathrm{ml}$ & $\mathrm{A} 2$ & 4 & 0 \\
\hline B.bassiana $10^{6} / \mathrm{ml}$ & A3 & 0 & 5 \\
\hline B.bassiana $10^{8} / \mathrm{ml}$ & A4 & 3 & 1 \\
\hline Sipermetrin $0,5 \mathrm{cc} / \mathrm{ml}$ & A5 & 0 & 0 \\
\hline Total & & 28 & 23 \\
\hline Persentase (\%) & & $54,90 \%$ & $45,10 \%$ \\
\hline
\end{tabular}

Tabel 4. Sidik Ragam Kepadatan Populasi Hama C.sordidus Pada Bonggol Pisang yang Terperangkap Pada Pengamatan 1 -3 hsp.

\begin{tabular}{lllll}
\hline \multirow{2}{*}{ Perlakuan } & Db & \multicolumn{3}{l}{ F.Hit } \\
\cline { 3 - 5 } & & 1 hsp & 2 hsp & 3 hsp \\
\hline Ulangan & 3 & 1,07 tn & 0,34 tn & 0,81 tn \\
Perlakuan & 5 & 2,47 tn & $3,64 *$ & $21,62 * *$ \\
\hline Kk & & $0,28 \%$ & $0,33 \%$ & $0,22 \%$ \\
\hline
\end{tabular}

Ket: $\mathrm{tn}=$ tidak nyata, ${ }^{*}=$ nyata, ${ }^{* *}=$ sangat nyata

Sidik ragam hama C.sordidus Germar pada 1 hsp - 3 hsp tertera pada tabel diatas, dari tabel diatas dijelaskan pada pengamatan 1 hsp pada perlakuan tidak nyata karena pada 1 hsp C.sordidus Germar yang terperangkap sebanyak 8 ekor dengan persentase $0,28 \%$, sedangkan pada pengamatan ke 2 hsp pada perlakuan nyata, karena C.sordidus yang terperangkap sebanyak 12 ekor dengan persentase 0,33\%. Pada 3 hsp menunjukan berpengaruh sangat nyata, karena C.sordidus Germar yang terperangkap sebanayak 12 ekor dengan persentase $0,22 \%$.Sedangkan sidik ragam jumlah hama O.longicollis Oliver pada batang pisang tertera pada Tabel dibawah ini. Serangga penggerek bonggol dan serangga penggerek batang pisang yang didapatkan setelah diidentifikasi dihitung jumlahnya.(Michael, 1984).
Tabel 5. Sidik Ragam Kepadatan Populasi Hama O.longicollis Pada Batang Pisang yang Terperangkap Pada Pengamatan 1-3 hsp

\begin{tabular}{lllll}
\hline \multirow{2}{*}{ Perlakuan } & Db & \multicolumn{3}{l}{ F.Hit } \\
\cline { 3 - 5 } & & 1 hsp & 2 hsp & 3 hsp \\
\hline Ulangan & 3 & 0,22 tn & 0,22 tn & 0,53 tn \\
Perlakuan & 5 & 1,38 th & 1,38 tn & $7,311^{* *}$ \\
\hline KK & $0,36 \%$ & $0,36 \%$ & $0,35 \%$ \\
\hline \multicolumn{5}{c}{ Ket: tn = Tidak nyata, ${ }^{*}=$ Nyata, ${ }^{* *}=$ Sangat nyata }
\end{tabular}

Sidik ragam diatas dijelaskan jumlah hama O.longicollis Oliver yang terdapat pada trap menunjukan berpengaruh sangat nyata pada pengamatan $3 \mathrm{hsp}$, karena pada hari pertama dan jumlah seluruh kumbang O.longicollis Oliver tidak begitu signifikan dibandingkan pada hari ketiga berpengaruh sangat nyata, karena terdapat 12 ekor O.longicollis Oliver dengan persentase 0,35\%. Serangga penggerek bonggol dan serangga penggerek batang pisang yang didapatkan setelah diidentifikasi dihitung jumlahnya.(Michael, 1984).

\section{Efektifitas Bioinsektisida B.bassiana}

Pada Tabel 3. hasil imago yang terperangkap dan persentasi imago C.sordidus. Pada perlakuan kontrol 0 ekor (0\%). A $10^{2} / \mathrm{ml} 0$ ekor (0\%). A $10^{4} / \mathrm{ml} 4$ ekor (57,14\%). A 106/ml 0 ekor (0\%). A $10^{8} / \mathrm{ml} 3$ ekor $(42,86 \%)$, dan Sipermetrin $0,5 \mathrm{cc} / \mathrm{ml} \quad 0$ ekor (0\%), sedangkan 
persentasi imago O.longicollis yang terperangkap pada perlakuan kontrol 0 ekor (0 \%), kepadatan $10^{2} / \mathrm{ml} 6$ ekor (50\%), suspensi $10^{4} / \mathrm{ml} 0$ ekor (0\%), suspensi $10^{6} / \mathrm{ml} 5$ ekor $(41,67 \%)$, suspensi $10^{8} / \mathrm{ml} 1$ ekor (8,33\%), dan Sipermetrin 0,5 cc/ml 0 (0\%). Menurut Nankinga et al. (1999b) menyatakan bahwa infeksi isolat jamur B.bassiana akan meningkat sejalan dengan meningkatnya pemberian dosis.

Tabel 6. Efektifitas Isolat B.bassiana sebagai Bioinsektisida (\%)

\begin{tabular}{lll}
\hline Perlakuan & Kode & $\begin{array}{l}\text { Efektifitas isolat } \\
\text { Bioinsektisida ( } \\
\text { C.sordidus }\end{array}$ \\
\hline Kontrol & A0 & 0 \\
B.bassiana $10^{2} / \mathrm{ml}$ & A1 & 0 \\
B.bassiana $10^{4} / \mathrm{ml}$ & A2 & 57,14 \\
B.bassiana $10^{6} / \mathrm{ml}$ & A3 & 0 \\
B.bassiana $10^{8} / \mathrm{ml}$ & A4 & 42,86 \\
Sipermetrin $0,5 \mathrm{cc} / \mathrm{ml}$ & A5 & 0 \\
\hline
\end{tabular}

Dari tabel 6. Efektifitas isolat B.bassiana pada perlakuan $\mathrm{A} 2=10^{4} / \mathrm{ml}$ mencapai $57,14 \%$ pada kumbang C.sordidus, sedangkan pada kumbang O.longicollis perlakuan A1 $=10^{2} / \mathrm{ml}$ mencapai $50 \%$.

Hal ini sesuai dengan Karolina et al. (2008) yang menyatakan bahwa gejala serangan pada serangga yang terinfeksi $B$. bassiana terlihat nafsu makan larva berkurang mengakibatkan larva menjadi kurang aktif, kemudian kaku dan diikuti perubahan warna tubuh karena dinding tubuhnya telah ditutupi oleh hifa yang berwarna putih, kemudian suhu juga sangat berperan penting dalam penginfeksian inangnya. Proses infeksi cendawan B.bassiana melalui saluran pencernaan serangga, sebelum konidia B.bassiana mencapai organ vital, terlebih dahulu berkecambah membentuk tabung kecambah dan hifa dipermukaan kulit sehingga menyebar keseluruh tubuh serangga. Di dalam tubuh serangga B.bassiana memperbanyak diri dan memproduksi toksin Beauverisin, toksin inilah yang merusak struktur membran sel, sehingga serangga mati juga merusak fungsi utama haemolimfa dan menyebabkan perubahan inti dan mempengaruhi perpindahan sel dalam deretan sel (Yasin et al, 2005).

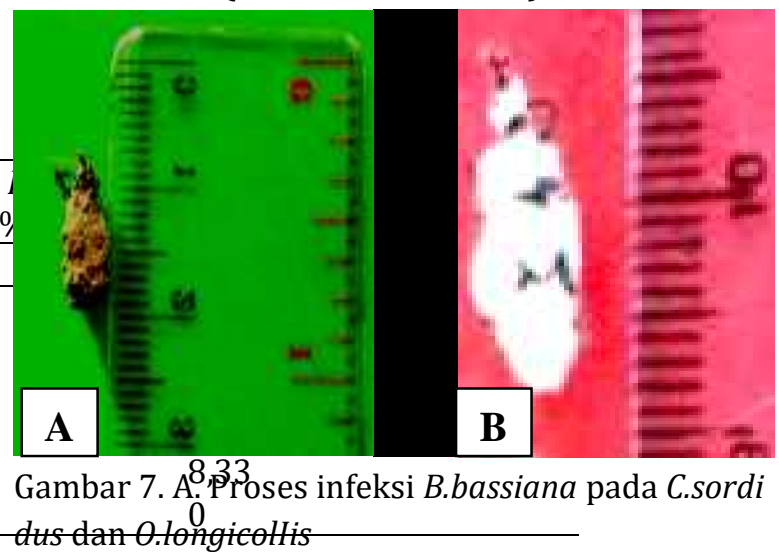

Dengan interval waktu selama 7 hari. (Dokumentasi pribadi 2014). B. Proses inf eksi B.bassiana pada C.sordidus. Sumber Azwana 2003.

Jamur $B$. bassiana juga dikenal sebagai penyakit white muscardine karena miselium dan konidium (spora) yang dihasilkan berwarna putih, bentuknya oval, dan tumbuh secara zig zag pada konidiofornya (Soetopo dan Indrayani, 2007). Hal ini sesuai dengan Karolina et al. (2008) yang menyatakan bahwa gejala serangan pada serangga yang terinfeksi $B$. bassiana terlihat nafsu makan larva berkurang mengakibatkan larva menjadi kurang aktif, kemudian kaku dan diikuti perubahan warna tubuh karena dinding tubuhnya telah ditutupi oleh hifa yang berwarna putih. Dengan demikian, pada akhirnya seluruh tubuh serangga inang akan penuh oleh propagul B. bassiana. Pada bagian lunak dari tubuh serangga 
inang, jamur ini akan menembus keluar dan menampakkan pertumbuhan hifa di bagian luar tubuh serangga inang yang biasa disebut "white bloom". Pertumbuhan hifa eksternal akan menghasilkan konidia yang bila telah masak akan disebarkan ke lingkungan dan menginfeksi serangga sasaran baru (Wahyudi, 2008). Dengan situasi perpisangan yang rusak berat akibat serangan kumbang penggerek bonggol pisang dan penggerek batang pisang di Sumatera Utara khususnya Kabupaten Deli Serdang, maka sangat diperlukan sebuah inovasi yang adaptif yang didukung oleh tekhnologi, dalam penyediaan cendawan entomopatogen B.bassiana sebagai pengendalian kumbang C.sordidus dan O.longicolli tersebut, selain mengendalikan serangan kumbang penggerek bonggol pisang dan penggerek batang pisang juga dapat meminimalisir serangan penyakit pada tanaman pisang akibat serangan kumbang tersebut, misalkan layu pisang, Fusarium oxysporum f.sp cubense (Foc) dan Blood Disease Bacterium (BDB).

Dengan cara atau metode ini diharapkan dapat mengatasi berbagai masalah yang dihadapi oleh para petani pisang dan masyarakat banyak tanpa harus menggunakan bahan kimia, maka dari itu timbulah inovasi yang ramah lingkungan dan ada beberapa alasan dipilihnya jamur entomopatogen dalam pengendalian hama, antara lain : kapasitas reproduksi yang tinggi, siklus hidupnya pendek, dapat membentuk spora yang bertahan lama di alam yaitu dengan menggunakan islolat jamur B.bassiana. Selain itu ada juga faktor yang tidak kalah penting yakni pemasangan disc on corm trap yang membantu untuk menjebak serangga masuk atau memancing serangga C.sordidus dan O.longicolli tersebut masuk keperangkap yang di letakkan di sekeliling batang pisang, dikarnakan batang pisang mengandung unsur fenolik yang mengandung gula dan protein yang disukai kumbang C.sordidus dan O.longicolli, jadi dapat diambil kesimpulan semua yang berasal dari alam sangat berguna dan bermamfaat untuk kehidupan sehari-hari dan kita sebagai manusia harus menyeimbangkan ekosistem dari alam tersebut dimamfaatkan dengan sebaik-baiknya agar berguna bagi masyarakat banyak dan diterapkan sebagai ilmu untuk kehidupan sehari-hari.

\section{SIMPULAN}

Aplikasi dengan B.bassiana dengan kerapatan 102-106 konidia/ml sudah mampu menunjukkan hasil yang sangat nyata untuk kematian serangga Cosmopolites sordidus Germar dan Odoiphorus longicollis Oliver di banding dengan perlakuan kontrol positif atau disc on corm trap perangkap yang tanpa diberi perlakuan B.bassiana dan control negatif atau sipermetrin $/ \mathrm{ml}$.

\section{DAFTAR PUSTAKA}

Atmadja, W. R., T. E, Wahyono, T. H. Savitri, dan E. Karmawati. 200o. Keefektifan beauveria bassiana Prosiding Seminar Nasional III Pengelolaan Serangga Yang Bijaksana Menuju Optimasi Produksi, Bogor, 6 November 2001.

Apriliani S., 2013. Produksi Pisang di Indonesia:Universitas Diponegoro.Jurnal Teknologi Kimia dan Industri : Vol. 1, No. 1.

Baharudin B. 1994. patologis, karakterisasi biokimia dan serologi dari bakteri penyakit darah mempengaruhi pisang dan perkebunan ( Musa sp .) Di Indonesia . Geotingen : Cuvillier Verlag 
Badan Pusat Statistik (BPS) Kabupaten Deli Serdang 2012

Dalam http://www.deliserdangkab.go.id/pendud uk-deli-serdang. diakses pada [Minggu, 5 Januari 2013] [22.00].

Cheung, P.Y.K. dan E.A. Grula . 1982. Dalam acara vivo terkait dengan entomopathology Beauveria bassiana untuk earworm jagung ( Heliothis zea ) .J.Invertebrate Patologi 39 : 303-313.

Daryanto. 2002. Langkah penanggulangan penyakit layu pisang di Indonesia. Makalah disampaikan pada Seminar Nasional Pengendalian Penyakit Layu Pi-sang: Mencegah kepunahan, mendukung ketahanan pangan dan agribisnis. Padang, 22-23 Oktober 2002.

Deptan go.id. (n.d). Penggerek bonggol pisang. Diakses 10 Desember 2014 dari cybex. Deptan.go.id/penyuluhan/penggerek bonggol.

Ditlin hortikultura Suputa, C. (2006). Luas serangan penyakit layu di Sumatera Utara [online] tersedia dalam http://.go.id/bukupeta/bagian-3.htm. [21 Feb 2006]

Ditlin hortikultura . (2012). Gejala serangan C.sordidus Germar . [online] tersedia dalam http://.go.id/buku-peta/ba. [21 Des 2012]

Gold, C.S And Meisan. 200o. Boilogy and integrated pest Management of Banana Weevil Cosmopolites sordidus (Germar).

Gulino , L dan W.O'Neill 2008, VCG / DNA Karakterisasi dan Foc Perpustakaan Department Industri primer dan Perikanan . Queensland Govertnment Australia 31 pp.

Herlinda S. 2010 kepadatan Spora dan kelangsungan hidup jamur entomopatogen isolat dari Indonesia , ( Homoptera : Aphididae ) . J. Tropic . Hidup Scien. Res . 21:13-21

Hermanto , C. , Jumjunidang ,. SEBUAH . Sutanto , Edison H.S.J. Daniel,

W .O'Neill . V Sinohin, dan Karakterisasi dan Konservasi sampel Foc di Indonesia dan Papua baru kemajuan guinea peport proyek ACIAR ada 2.005 / 136.17.pp

Hadiwiyono.. 2011. Insiden penyakit layu bakteri darah dan layu fusarium pisang. Agrosains 12(1):19-23

Junianto, Y.D. dan E. Sulistyowati. 2002. Formulasi agen hayati Beauveria bassiana dan uji lapangan pengendalian penggerek $b$ uah kopi,

Hypothenemus hampei.Pelita Perkebunan 18 (3) $: 129-138$
Karolina E; Mahfud MC; Rachmawati D; Sarwono \& Fatimah S. 2008. Pengkajian efektifitas Cendawan Beauveria bassiana terhadap Perkembangan Hama dan Penyakit Tanaman.

Marwan, H.,Sinaga, S.M.Giyanto, \& Nawangsih, A.A. 2011. Isolasi dan seleksi bakteriendofit untuk pengendalian penyakit darah pada tanaman pisang. J. HPT Tropika 11(2):113-121.

Muharam , A. , Dan Subiyanto . 1991. Status penyakit pisang di Indonesia . Dalam penyakit Pisang di Asia dan Pasifik . INIBAP

Nasir , 2005. Fusarium oxysporum cubense patogen tular tanah yang paling berbahaya di dunia ini menyerang tanaman pisang dari berbagai kelompok umur.

-,2007. Strategi peningkatan nilai industri pisang vs penyakit layu : Kebijakan pemanfaatan tehnologi dan komitmen para pelaku di Indonesia. Makalah disampaikan di :Seminar nasional Strategi dan dukungan inovasi dalam pengembangan agribisnis hortikultura di Indonesia. BPTP Sumatera Barat Padang 13 desember 2007.

Ploetz , R. C, J. Thomas E. dan W. R. Slabaugh . 2003. Penyakit pisang. Dalam : Penyakit tanaman buah tropis . CABI Publ .

Rohmawana, E. 1998. Seleksi Media Perbanyakan Massal Jamur Entomopatogen Isolat Adal Ulat Penggulung Daun Pisang (Erionota thrax L.) dan Uji Patogenisitasnya terhadap Spodoptera exigua Hubn. (Lepidoptera; Noctuidae) di Rumah Kaca. Skripsi. Faperta, UNPAD, Bandung. 6o hal.

Tanada, Y. H. Kaya .1993 dan Yasin 2005. Insect Pathology. Academic Press Inc., San Diego, New York, Boston, London, Sydney, Tokyo, Toronto. $366 \mathrm{P}$.

Supriyadi,. 2008. "Pengembangan dan persebaran pisang” konsumsi dalam negeri dan ekspor. Ringkasan Eksekutif Hasil-hasil Penelitian.

Sunyoto, Ade. 2011. Budidaya Pisang Barangan. alternatif terbaik, sebagai sumber energi pada saat istirahat Berlian Media. Yogyakarta.

Susnihati N,. Sumeno. \& Suderajat. 2005. Bahan ajar ilmu hama tumbuhan Yogyakarta

Sutopo D, Indriyani IGAA. 2007. Status, Teknologi, dan Prospek B. Bassiana Untuk Pengendalian Serangga Hama. Balai Penelitian Tanaman Tembakau dan Serat. Malang. 
Umeh, C. N., Okorie, O. I. and Emesiani, G. A. (2005). Towards the provision of safe drinking water: The bacteriological quality and safety of sachet water in Awka, Anambra State. In: the Book of Abstract of the 29th Annual Conference \& General Meeting on Microbes As Agents of Sustainable Development, organized by Nigerian Society for Microbiology (NSM), University of Agriculture, Abeokuta, pp. 22 